\title{
Cultural approach to industrial heritage reuse: experiences from Shanghai, China
}

\author{
Jie CHEN, Tongji University, China \\ Yiming WANG, Tongji University, China
}

\begin{abstract}
Cultural approach has been gradually applied to urban regeneration practices. The scholars identified the progressive, creative and entrepreneurial cultural strategy in urban regeneration, and summarised four aspects of characteristics. These approaches form the theoretical framework within which to classify diverse sets of industrial heritage precincts. A scoping study of cases of industrial heritage reuse in Shanghai was undertaken based on this progressive, creative and entrepreneurial cultural framework. The selected cases have common characteristics: inhabiting the former abandoned industrial areas and having been changed to the three cultural uses. The scoping study investigates the commencement time of the adaptive reuse, the original factory characteristics, cultural approach, current precinct type, tenants and the reuse process. By summarising Shanghai's experience on industrial heritage reuse, this paper expanded the main characteristics of the progressive, creative and entrepreneurial cultural approaches into seven aspects, namely, architectural type, potential value, goals, main stakeholders, target audience, type of cultural programs and facilities, and cultural activities. This paper attempts to in enrich existing literature on urban regeneration and heritage conservation, and provide a reference to the industrial land regeneration practice in China.
\end{abstract}

\section{Keywords}

Urban regeneration, cultural approach, industrial heritage, adaptive reuse, Shanghai, experience

\section{Introduction}

As a means of bringing about the regeneration of declining urban areas, cultural development strategies are utilised in inner urban areas, through which the public realm is to be reconfigured (Montgomery, 2003; O'Connor, 2011). The prevailing response by practitioners and policy makers is to devise a broad range of cultural development strategies (Griffiths, 1995; Grodach and Loukaitou-Sideris, 2007; O'Connor, 2011). These strategies tend to combine urban planning and development policies for greater promotion of cultural production and consumption. The formulation of cultural approaches has been gradually applied to urban regeneration practices in North America, Europe and Asia, including China. Since Chinese industrial cities entered into a new development stage with a transformation of industry sites, the regeneration of the inner-city historical industrial sites became an urgent task for local authorities. One widely-seen regeneration method is the adaptive reuse of the abandon industrial heritage sites as cultural precincts in the eastern leading cities in China. Shanghai, as the showcases of the leading cities in 
China, has rich experience in industrial heritage reuse. This paper investigates the cases of industrial heritage reuse in Shanghai based on this progressive, creative and entrepreneurial cultural framework, and summarizes the main characteristics of the progressive, creative and entrepreneurial cultural approaches to industrial heritage reuse.

\section{The adaptive reuse of industrial heritage}

Heritage has been gaining recognition as one of the most important means of representing "the cultural identity of communities, groups and individuals, and or social cohesion" (UNESCO, 2003). Heritage conservation has thus been used to recognise cultural diversity (Logan, 2012; Langfield et al., 2010) and as a major part of urban regeneration. The leading international organisations in heritage conservation include UNESCO (United Nations Educational Scientific and Cultural Organisation), ICOMOS (International Council on Monuments and Sties), and TICCIH (International Committee for the Conservation of the Industrial Heritage) (Ahmad, 2006; Logan, 2001; Taylor, 2004). These cultural bodies have been laying down international standards for 'world best practice', promoting heritage values, establishing management guidelines and principles, as well as formulating fundamental methodologies for heritage sites (Logan, 2001, p.52-53).

For the last 40 years, the scope of heritage was broadened significantly since the adoption of the Venice Charter in 1964 (see Ahmad, 2006; Taylor, 2004; Vecco, 2010, for the review of heritage histories). Heritage was initially concerned with 'historic monuments' ${ }^{1}$, and was defined as 'monuments and sites' in the Constitutive Assembly Meeting of ICOMOS in $1965^{2}$. The UNESCO Convention regarded heritage as both cultural heritage and natural heritage in 1972, including monuments, groups of buildings and sites ${ }^{3}$. The scope of heritage was shifted to include historic gardens in the Florence Charter in $1982^{4}$, and historic towns and urban areas in the Washington Charter in $1987^{5}$. During the 1990 s and 2000s, the term heritage was broadened again, to embrace tangible and intangible heritage as well as environments ${ }^{6}$ (Ahmad, 2006; Landorf, 2009; Logan,2007; Vecco, 2010). Industrial heritage was officially considered as a significant type of heritage since the creation of the Nizhny Tagil Charter in 20037 (Douet, 2013). According to the Nizhny Tagil Charter, the subjects of industrial heritage include "the remains of industrial culture which are of historical, technological, social, architectural or scientific value" (TICCIH, 2003, Article 1, p.1), and "buildings and machinery, workshops, mills and factories, mines and sites for processing and refining, warehouses and stores, places where energy is generated, transmitted and used, transport and all its infrastructure, as well as places used for social activities related to industry such as housing religious worship or education" (TICCIH, 2003, Article 1, p.1).

The term of adaptive reuse refers to change of use within the original structure of a building to conserve it (Wilkinson et al., 2014). Adaptive reuse has been widely accepted as the act for finding a new use of ahistorical industrial sites and buildings (Bullen, 2007; Chen et al., 2016; Wilkinson et al., 2014). As the Nizhny Tagil Charter stated, "the adaptation of an industrial site to a new use ensuring its conservation is usually acceptable... new uses should respect the significant material and maintain the original patterns of circulation and activity, and should be compatible as much as possible with the original or principle use" (TICCIH, 2003, Article 5, p.3).

\footnotetext{
${ }^{1}$ Congress of Architects and Technicians of Historic Monuments, the Venice Charter, 1964

${ }^{2}$ ICOMOS, Constitutive Assembly, 1965

${ }^{3}$ UNESCO, the World Heritage Convention (also known as Convention Concerning the Protection of the World Cultural and Natural Heritage), 1972

${ }^{4}$ ICOMOS, the Florence Charter, 1982

${ }^{5}$ ICOMOS, the Washington Charter (also known as Charter for the Conservation of Historic Towns and Urban Areas), 1987

${ }^{6}$ UNESCO, the Convention for the Safeguarding of the Intangible Cultural Heritage, 2003

${ }^{7} \mathrm{TICCIH}$, the Nizhny Tagil Charter, 2003
} 


\section{The cultural approach to re-using industrial heritage}

As reviewed from the literature on cultural strategies employed in urban regeneration, this section identifies the main types of cultural approach as taken to industrial heritage reuse. First, as Montgomery (2003, p.296) argues, the pre-requisite for a cultural approach is the presence of cultural activities, such as cultural production, cultural consumption, and their combination (Evans, 2009; Montgomery, 2003). Second, Yuen (2013) has detailed the types of major cultural programs in urban regeneration, including iconic cultural mega-projects, creative industries programs, and service-oriented precincts. Third, Griffiths (1995) has identified three cultural policy models, including the integrationist model, cultural industries model and consumerist model. Fourth, based on a normative set of cultural characteristics, Grodach and Loukaitou-Sideris (2007) have conceptualised three cultural development strategies: the progressive strategy, creative class strategy and entrepreneurial strategy. In combination with the above researches, following the approaches of 'progressive', 'creative' and 'entrepreneurial', the cultural precincts reusing industrial heritage in this paper are in the forms of 'public cultural precincts', 'creative class clusters' and 'service-oriented precincts', as elaborated in Table 1. The key terms in Table 1 include precinct type, main goals, key actors, target audiences, cultural projects and programs, cultural activity and geographic focus. These key terms are consistent with those used to describe cultural approaches to industrial heritage reuse, for example, by Evans (2009), Yuen (2013), Griffiths (1995), as well as Grodach and LoukaitouSideris (2007). These approaches form the framework within which to classify diverse sets of cultural precincts in Chinese-mega cities, discussed in the next sections.

Table 1: Cultural approaches to industrial heritage reuse

\begin{tabular}{|c|c|c|c|}
\hline Approach & Progressive & Creative & Entrepreneurial \\
\hline Precinct type & Public cultural precincts & Creative class clusters & Service-oriented precincts \\
\hline Main goals & $\begin{array}{l}\text { Strengthen community } \\
\text { identity and } \\
\text { development } \\
\text { Widen access to and } \\
\text { participation to the social } \\
\text { public life } \\
\text { Support local cultural } \\
\text { production }\end{array}$ & $\begin{array}{l}\text { Promote sectors of the } \\
\text { economy in cultural and } \\
\text { creative industry }\end{array}$ & $\begin{array}{l}\text { Economic growth through } \\
\text { tourism } \\
\text { City image branding } \\
\text { Attract private sector } \\
\text { investments }\end{array}$ \\
\hline Key actors & $\begin{array}{l}\text { Local government } \\
\text { Public sectors }\end{array}$ & $\begin{array}{l}\text { Public sector covering } \\
\text { culture, media and } \\
\text { creative industry } \\
\text { Private sector and } \\
\text { special agencies }\end{array}$ & $\begin{array}{l}\text { National and municipal } \\
\text { government } \\
\text { Public-private- partnership } \\
\text { as the dominant approach } \\
\text { Private developers }\end{array}$ \\
\hline Target audiences & $\begin{array}{l}\text { General community } \\
\text { Underserved residential } \\
\text { population }\end{array}$ & $\begin{array}{l}\text { Prospective residents } \\
\text { Creative class }\end{array}$ & $\begin{array}{l}\text { Affluent residents } \\
\text { Tourists }\end{array}$ \\
\hline $\begin{array}{l}\text { Cultural projects } \\
\text { and programs }\end{array}$ & $\begin{array}{l}\text { Public parks } \\
\text { Arts education program }\end{array}$ & $\begin{array}{l}\text { Arts and entertainment } \\
\text { venues } \\
\text { Private or public owned }\end{array}$ & $\begin{array}{l}\text { Iconic cultural buildings and } \\
\text { landmarks } \\
\text { Service-oriented facilities: }\end{array}$ \\
\hline
\end{tabular}




\begin{tabular}{|c|c|c|c|}
\hline & $\begin{array}{l}\text { Public arts centres } \\
\text { City-operated community } \\
\text { arts spaces } \\
\text { Neighbourhood arts } \\
\text { organisations }\end{array}$ & $\begin{array}{l}\text { art galleries and } \\
\text { institutions } \\
\text { Independent artist's } \\
\text { studios } \\
\text { Private companies in } \\
\text { cultural and creative } \\
\text { industries } \\
\text { Artwork market and } \\
\text { festivals }\end{array}$ & $\begin{array}{l}\text { e.g. art galleries, } \\
\text { restaurants, clubs, bars, and } \\
\text { shopping malls } \\
\text { Business and entertainment } \\
\text { districts } \\
\text { Mega-cultural festivals and } \\
\text { events }\end{array}$ \\
\hline Cultural activity & Cultural consumption & $\begin{array}{l}\text { Cultural mono- / poly- } \\
\text { production } \\
\text { Cultural production and } \\
\text { consumption }\end{array}$ & $\begin{array}{l}\text { Cultural production and } \\
\text { consumption }\end{array}$ \\
\hline Geographic focus & $\begin{array}{l}\text { Inner-city or underserved } \\
\text { neighbourhoods }\end{array}$ & $\begin{array}{l}\text { Historic urban } \\
\text { neighbourhoods }\end{array}$ & Downtown \\
\hline
\end{tabular}

Source: Based on Bianchini (1993), Griffiths (1995), Grodach and Loukaitou-Sideris (2007) and Yuen (2013)

\section{Case study in Shanghai}

This paper chooses Shanghai as the case city of industrial heritage reuse in China. Shanghai was forced to serve as trading ports to western Countries after the Chinese defeat in the First Anglo-Chinese War (1840-1842). Up until today, rich industrial heritage, ranging from small-scale "house manufacturing workshops" (Lilong zuofang in Chinese) to the huge-scale state-owned enterprises (SOEs) and urban infrastructure for the concessions, was remained in Shanghai. Shanghai has been concerned with its international reputation as a global city. To compete with other large Chinese cities, the Shanghai Municipal Government was active in the promotion of local cultural influence. Adaptive reuse of industrial heritage as cultural clusters is one important cultural development strategy to urban regeneration in the inner-city industrial sites. The Creative Industry Clusters (CICs) policy in Shanghai makes an important contribution to heritage reuse outcomes. A CIC is a type of urban precinct re-using from the former industrial sites and possessing "a high concentration of cultural activities and creative industry companies" (Roodhouse, 2006; Zheng and Chan, 2014, p.9). Inspired by the movement of local artists into old industrial sites, and also by the expansion of the tertiary sector of the urban economy, Shanghai authorities recognised the value of combining economic restructuring and urban cultural development in the inner city industrial sites (Wu, 2004). With the introduction of the term 'creative industry', the Shanghai Economic Committee set up the CICs in 2004. They allowed the owners of landuse rights to charge high commercial rents for industrial land without paying fees for the formal redesignation (O'Connor and Gu, 2014). To attract more artists, professionals and developers to participate, the Shanghai government implemented preferential policies such as tax concessions and special funding for the combination of industrial heritage and creative industry. A new policy called the 'three nonchange and five changes' (sanbian wububian) was introduced to regulate the reuse of the old industrial buildings. It involved maintaining ownership of premises, old building structures and land status by the old SOEs (three non-changes), while allowing changes in employment structure, management, type of tenants, form of business organisation and enterprise culture (five changes) (Zheng, 2011). Under the 
influence of the government's preferential policy, from 2005 to 2020, the CICs spread rapidly across Shanghai expanding from 18 to 138 establishments in four rounds of re-designation.

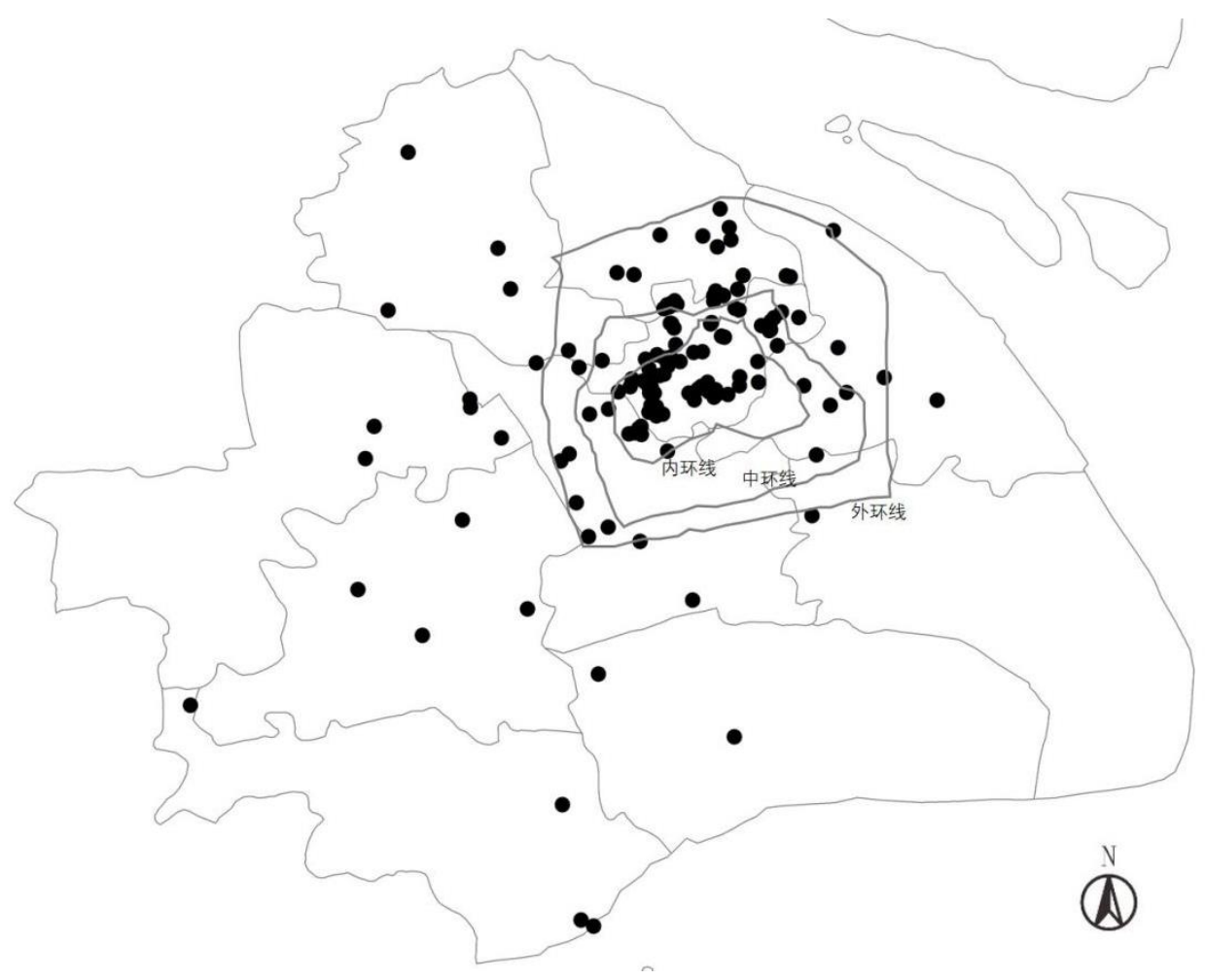

Figure 1: The Spatial Layout of the Creative Industry Clusters in Shanghai. Source: by the authors

A scoping study of examples of industrial heritage reuse in Shanghai was undertaken by the researcher in 2020, as summarized in Table 2, based on the progressive, creative and entrepreneurial cultural framework. These selected cases have common characteristics: which used to be industrial areas and have been changed to the three cultural uses described above. The scoping study investigates the commencement time of the adaptive reuse, the original factory, cultural approach, precinct type, tenants, the reuse process.

Table 2: Selected examples of industrial-heritage cultrual precincts in Shanghai

\begin{tabular}{l|l|l|l|l|l|l}
\hline $\begin{array}{l}\text { Precinct } \\
\text { name }\end{array}$ & Time & $\begin{array}{l}\text { Original } \\
\text { factory }\end{array}$ & Approach & Precinct & Tenant & Process \\
\hline M50 & $\begin{array}{l}1990 \\
\mathrm{~s}\end{array}$ & $\begin{array}{l}\text { Textile } \\
\text { factory }\end{array}$ & Creative & $\begin{array}{l}\text { Creative } \\
\text { class } \\
\text { cluster }\end{array}$ & $\begin{array}{l}\text { Independent } \\
\text { artists and } \\
\text { design } \\
\text { companies }\end{array}$ & Bottom-up \\
\hline Tianzifang & 1990 & $\begin{array}{l}\text { Li-long } \\
\text { factory }\end{array}$ & Creative & $\begin{array}{l}\text { Creative } \\
\text { class } \\
\text { cluster }\end{array}$ & $\begin{array}{l}\text { Independent } \\
\text { artists and } \\
\text { artwork stores }\end{array}$ & Bottom-up \\
\hline South Creek & 1999 & Warehouse & Creative & $\begin{array}{l}\text { Creative } \\
\text { class }\end{array}$ & $\begin{array}{l}\text { Independent } \\
\text { artists }\end{array}$ & Bottom-up \\
\hline
\end{tabular}




\begin{tabular}{|c|c|c|c|c|c|c|}
\hline & & & & cluster & & \\
\hline $\begin{array}{l}\text { Sihang } \\
\text { Creation } \\
\text { Warehouse }\end{array}$ & 1999 & Warehouse & Creative & $\begin{array}{l}\text { Creative } \\
\text { class } \\
\text { cluster }\end{array}$ & $\begin{array}{l}\text { Independent } \\
\text { artists and } \\
\text { design } \\
\text { companies }\end{array}$ & Bottom-up \\
\hline Creekart & 2005 & Flour factory & Creative & $\begin{array}{l}\text { Creative } \\
\text { class } \\
\text { cluster }\end{array}$ & $\begin{array}{l}\text { Art exhibition } \\
\text { and restaurants }\end{array}$ & Bottom-up \\
\hline No.8 Bridge & 2003 & $\begin{array}{l}\text { Motor parts } \\
\text { factory }\end{array}$ & Creative & $\begin{array}{l}\text { Creative } \\
\text { class } \\
\text { cluster }\end{array}$ & $\begin{array}{l}\text { Design } \\
\text { companies, art } \\
\text { exhibition and } \\
\text { restaurants }\end{array}$ & $\begin{array}{l}\text { Private } \\
\text { development }\end{array}$ \\
\hline $\begin{array}{l}\text { Jingan } \\
\text { Industrial } \\
\text { Park }\end{array}$ & 2004 & Radio factory & Creative & $\begin{array}{l}\text { Creative } \\
\text { class } \\
\text { cluster }\end{array}$ & $\begin{array}{l}\text { Design } \\
\text { companies }\end{array}$ & $\begin{array}{l}\text { Private } \\
\text { development }\end{array}$ \\
\hline $\begin{array}{l}\text { X2 Creative } \\
\text { Space }\end{array}$ & 2005 & Printing plant & Creative & $\begin{array}{l}\text { Creative } \\
\text { class } \\
\text { cluster }\end{array}$ & $\begin{array}{l}\text { Design } \\
\text { companies }\end{array}$ & $\begin{array}{l}\text { Private } \\
\text { development }\end{array}$ \\
\hline $\begin{array}{l}\text { Zhongke } \\
\text { Creative } \\
\text { Warehouse }\end{array}$ & 2005 & $\begin{array}{l}\text { Cotton } \\
\text { warehouse }\end{array}$ & Creative & $\begin{array}{l}\text { Creative } \\
\text { class } \\
\text { cluster }\end{array}$ & $\begin{array}{l}\text { Design } \\
\text { companies }\end{array}$ & $\begin{array}{l}\text { Public- } \\
\text { private- } \\
\text { partnership }\end{array}$ \\
\hline Tonglefang & 2005 & $\begin{array}{l}\text { Li-long } \\
\text { factory }\end{array}$ & $\begin{array}{l}\text { Entrepreneuria } \\
\text { I }\end{array}$ & $\begin{array}{l}\text { Service- } \\
\text { oriented } \\
\text { precinct }\end{array}$ & $\begin{array}{l}\text { Galleries, } \\
\text { restaurants and } \\
\text { stores }\end{array}$ & $\begin{array}{l}\text { Private } \\
\text { development }\end{array}$ \\
\hline Warehouse E & 2006 & $\begin{array}{l}\text { Motor parts } \\
\text { warehouse }\end{array}$ & Creative & $\begin{array}{l}\text { Creative } \\
\text { class } \\
\text { cluster }\end{array}$ & $\begin{array}{l}\text { Design } \\
\text { companies, art } \\
\text { exhibition and } \\
\text { restaurants }\end{array}$ & $\begin{array}{l}\text { Private } \\
\text { development }\end{array}$ \\
\hline $\begin{array}{l}1933 \text { Old } \\
\text { Millfun }\end{array}$ & 1933 & $\begin{array}{l}\text { Slaughterhou } \\
\text { se }\end{array}$ & $\begin{array}{l}\text { Entrepreneuria } \\
\text { I }\end{array}$ & $\begin{array}{l}\text { Service- } \\
\text { oriented } \\
\text { precinct }\end{array}$ & $\begin{array}{l}\text { Stores, art } \\
\text { exhibition and } \\
\text { restaurants }\end{array}$ & $\begin{array}{l}\text { Private } \\
\text { development }\end{array}$ \\
\hline Husizhan & 2006 & $\begin{array}{l}\text { Cotton } \\
\text { factory }\end{array}$ & Creative & $\begin{array}{l}\text { Creative } \\
\text { class } \\
\text { cluster }\end{array}$ & $\begin{array}{l}\text { Design } \\
\text { companies }\end{array}$ & $\begin{array}{l}\text { Private } \\
\text { development }\end{array}$ \\
\hline Shangjie Loft & 2007 & $\begin{array}{l}\text { Cotton } \\
\text { factory }\end{array}$ & $\begin{array}{l}\text { Entrepreneuria } \\
\text { I }\end{array}$ & $\begin{array}{l}\text { Service- } \\
\text { oriented } \\
\text { precinct }\end{array}$ & $\begin{array}{l}\text { Design } \\
\text { companies and } \\
\text { stores }\end{array}$ & $\begin{array}{l}\text { Private } \\
\text { development }\end{array}$ \\
\hline $\begin{array}{l}\text { Chuangyi } \\
\text { Jinshagu }\end{array}$ & 2007 & Clutch factory & Creative & $\begin{array}{l}\text { Creative } \\
\text { class } \\
\text { cluster }\end{array}$ & $\begin{array}{l}\text { Design } \\
\text { companies and } \\
\text { stores }\end{array}$ & $\begin{array}{l}\text { Private } \\
\text { development }\end{array}$ \\
\hline $\begin{array}{l}\text { Yuejie } \\
\text { Creative }\end{array}$ & 2007 & $\begin{array}{l}\text { Television } \\
\text { factory }\end{array}$ & Creative & $\begin{array}{l}\text { Creative } \\
\text { class }\end{array}$ & $\begin{array}{l}\text { Design } \\
\text { companies and }\end{array}$ & $\begin{array}{l}\text { Private } \\
\text { development }\end{array}$ \\
\hline
\end{tabular}




\begin{tabular}{|c|c|c|c|c|c|c|}
\hline Zone & & & & cluster & stores & \\
\hline $\begin{array}{l}\text { Allory } \\
\text { Factory }\end{array}$ & 2007 & Allory factory & Creative & $\begin{array}{l}\text { Creative } \\
\text { class } \\
\text { cluster }\end{array}$ & $\begin{array}{l}\text { Media } \\
\text { companies }\end{array}$ & $\begin{array}{l}\text { Private } \\
\text { development }\end{array}$ \\
\hline $\begin{array}{l}\text { Wending } \\
\text { Living Style } \\
\text { Plaza }\end{array}$ & 2008 & $\begin{array}{l}\text { Cold drawn } \\
\text { steel plant }\end{array}$ & $\begin{array}{l}\text { Entrepreneuria } \\
\text { । }\end{array}$ & $\begin{array}{l}\text { Service- } \\
\text { oriented } \\
\text { precinct }\end{array}$ & $\begin{array}{l}\text { Media } \\
\text { companies, } \\
\text { stores, and } \\
\text { restaurants }\end{array}$ & $\begin{array}{l}\text { Private } \\
\text { development }\end{array}$ \\
\hline $\begin{array}{l}\text { JC Film } \\
\text { Gallery }\end{array}$ & 2014 & $\begin{array}{l}\text { Machinery } \\
\text { plant }\end{array}$ & Progressive & $\begin{array}{l}\text { Public } \\
\text { cultural } \\
\text { precinct }\end{array}$ & museum & $\begin{array}{l}\text { Private } \\
\text { development }\end{array}$ \\
\hline $\begin{array}{l}\text { Shanghai } \\
\text { Sculpture } \\
\text { Space }\end{array}$ & 2004 & Steel plant & Progressive & $\begin{array}{l}\text { Public } \\
\text { cultural } \\
\text { precinct }\end{array}$ & $\begin{array}{l}\text { Public park, } \\
\text { museum and } \\
\text { design } \\
\text { companies }\end{array}$ & Top-down \\
\hline 2010 Expo & 2010 & $\begin{array}{l}\text { Factories } \\
\text { cluster }\end{array}$ & Progressive & $\begin{array}{l}\text { Public } \\
\text { cultural } \\
\text { precinct }\end{array}$ & $\begin{array}{l}\text { Public park, } \\
\text { museum and } \\
\text { design } \\
\text { companies }\end{array}$ & Top-down \\
\hline
\end{tabular}

Source: Based on the information from the author's field reconnaissance in 2020 and internet searches

\section{The Cultural Approach to Industrial Heritage Reuse in Shanghai}

In the progressive approach, the 'public cultural precinct' aims at providing opportunities for participation in the public social life, widening access to the arts, and utilising high-quality art to revive the sense of community and improve the image of neighbourhoods (Bianchini, 1993; Griffiths, 1995; Grodach and Loukaitou-Sideris, 2007). Major actors include local governments and the public sectors. Examples include city-operated community art spaces and neighbourhood arts organisations (Grodach and Loukaitou-Sideris, 2007), education facilities, public parks, museums and/or exhibition spaces. Such cases in Shanghai include the Shanghai International Sculpture Space and Shanghai Yangpu Waterfront Park, as shown in Figure 2 and 3. 


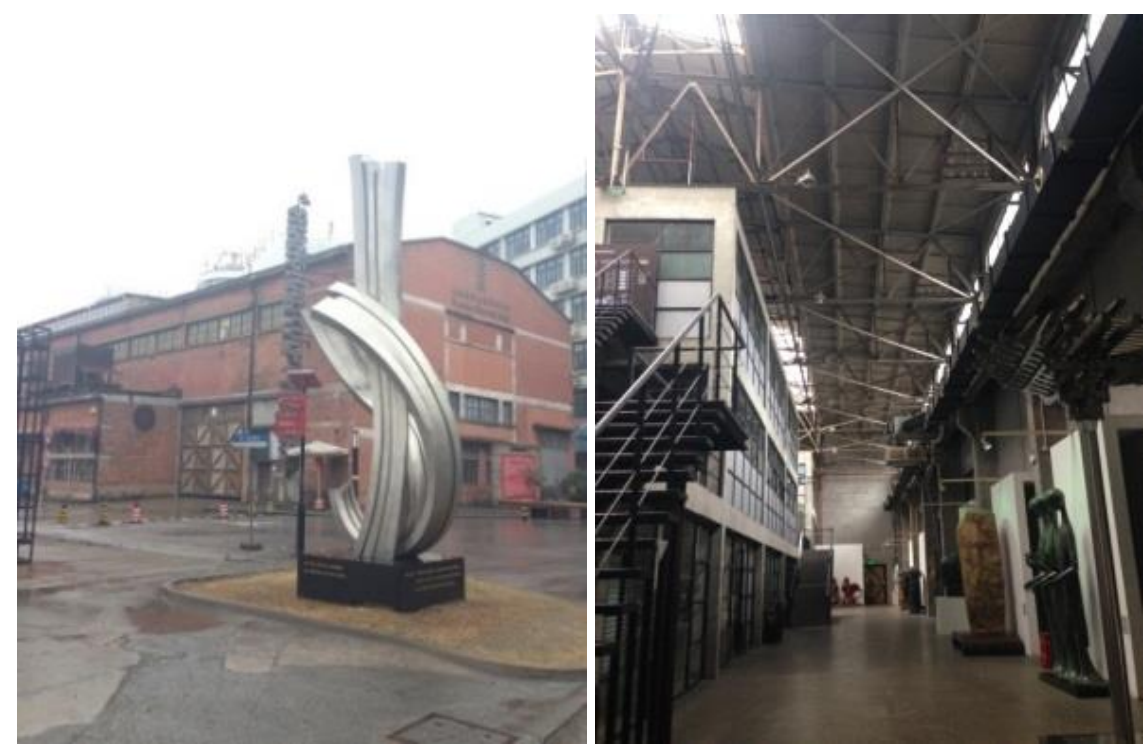

Figure 2: Shanghai International Sculpture Space. Source: photo by the authors

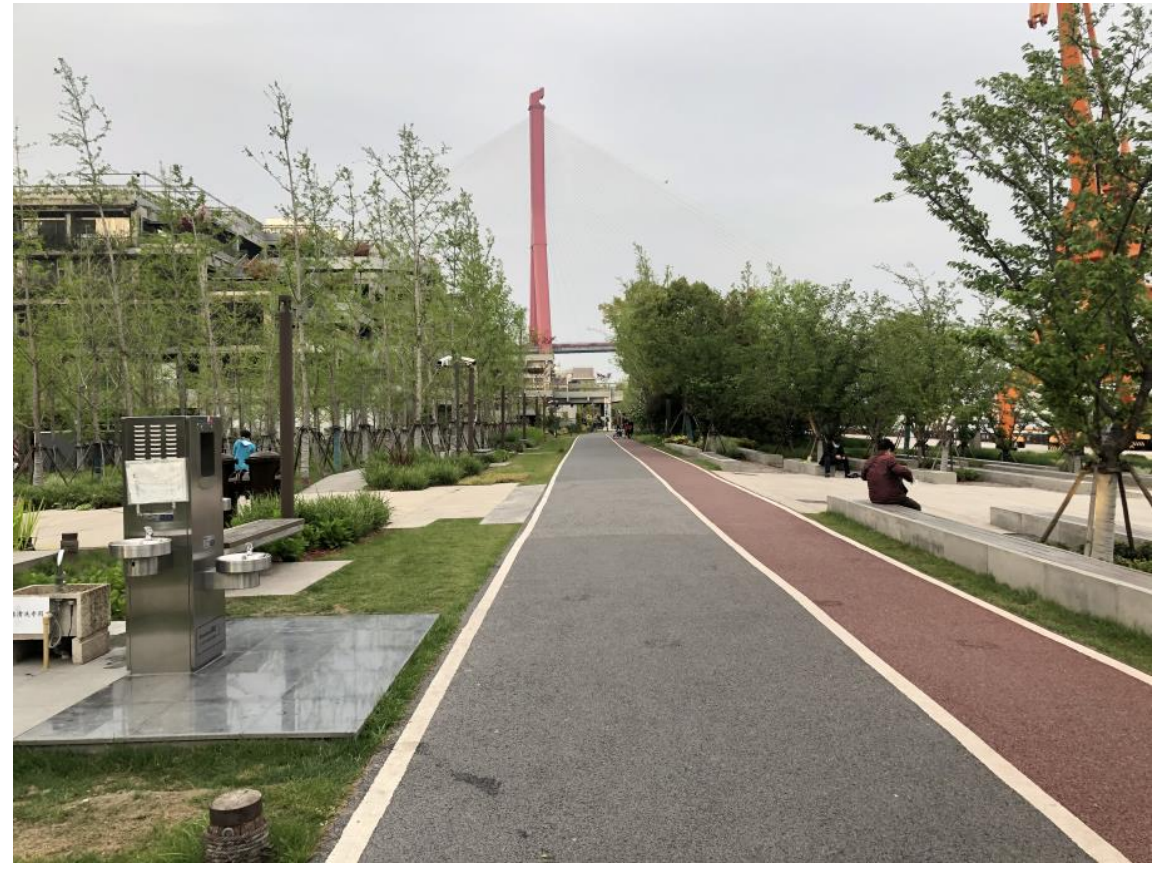

Figure 3: Shanghai International Sculpture Space. Source: photo by the authors

In the creative approach, the 'creative class cluster' aims at developing sectors of the economy in the cultural and creative industries (Scott, 1997), covering "cinema and audio-visual arts, design and crafts, media arts, music, performing arts, publishing and visual arts" (UNESCO, 2015, p.1). The target audience is the 'creative class' (Florida, 2002), namely, highly educated workers and 'knowledge-based professionals' (Grodach and Loukaitou-Sideris, 2007), and those whose occupations "range from artists and software designers (the super-creative core) to management and legal experts (the creative professionals)" (Pratt, 2008, p. 108). Major actors include government departments of creative industries, private sectors and special agencies that are established by local governments for the management and 
operation of creative class clusters. Examples cover independent artist's studios, companies in the cultural and creative industries, and private or public owned art galleries. In Shanghai, Tianzifang, M50, the Bridge No.8 and 1933 Old Millfun are the cases of the creative approach to industrial heritage reuse, as shown in Figure 4. Tianzifang and M50 are two examples of cultural clusters reused by local successful and more commercially oriented 'sea culture' artists. The artists were attracted by the large spaces and historic atmosphere of industrial sites and reused the factories as the creative industry studios. The Bridge No.8 was another example of cultural cluster reused by a private property developer. The property developer has invested in the refurbishment of a motor parts plant, reused the factory as the creative hub and then charged high commercial rents to international and local design companies. The creative approach benefits those who combine 'art, creativity and entrepreneurship' in Shanghai (Wang, 2009). The private sectors rent the assets of local SOEs, and then invest with a low cost of refurbishment, while charges high commercial rents from the new tenants (O'Connor and $\mathrm{Gu}, 2014$ ).

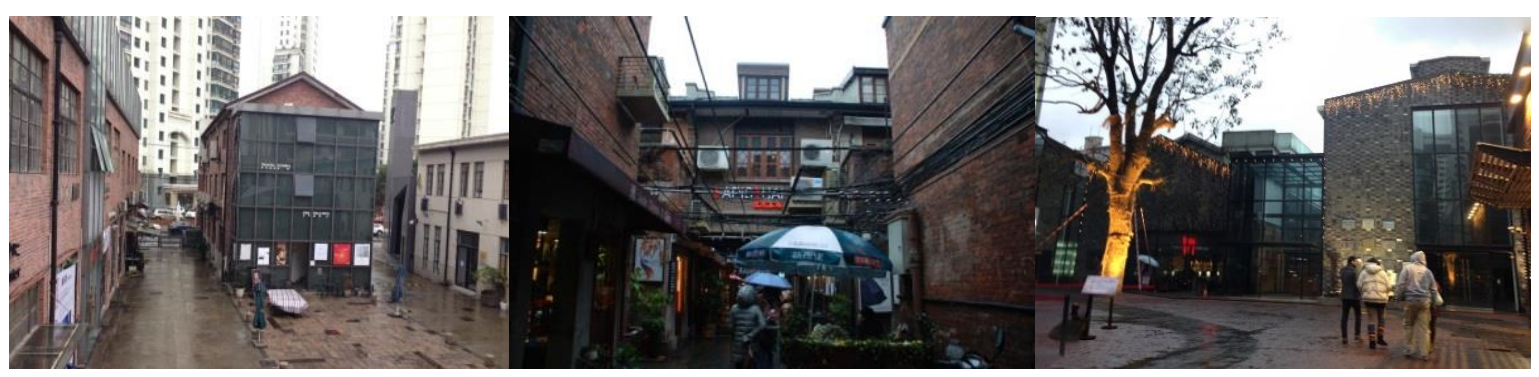

Figure 4: Photos from left to right: M50, Tianzifang, the Bridge No.8. Source: photos by the authors

In the entrepreneurial approach, the 'service-oriented precinct' seeks to create an attractive business environment by providing high-profile facilities and events, iconic architecture and landscape (Grodach and Loukaitou-Sideris, 2007). The main goals in these kinds of strategies coincide with city government's broader entrepreneurial agenda, including fostering private developments, generating local tax, boosting consumption, branding the city image as 'a place to play', and promoting economic growth in the tourism, cultural and information technology industries (Grodach and Loukaitou-Sideris, 2007; Judd and Fainstein, 1999; Scott, 1997). Major actors include city governments and private developers with the dominance of public-private partnerships. The presence of cultural facilities for an evening economy, such as bars and night clubs, the construction of iconic flagship cultural complexes, and the celebration of spectacular cultural events are included. Figure 5 shows the Shanghai 2010 Expo, the most notable example of the entrepreneurial approach to industrial site reuse in Shanghai. $5.28 \mathrm{~km}^{2}$ of industrial sites along the Huangpu River were reused as the Shanghai 2010 Expo to celebrate Shanghai's industrial development history, (Deng and Poon, 2012).

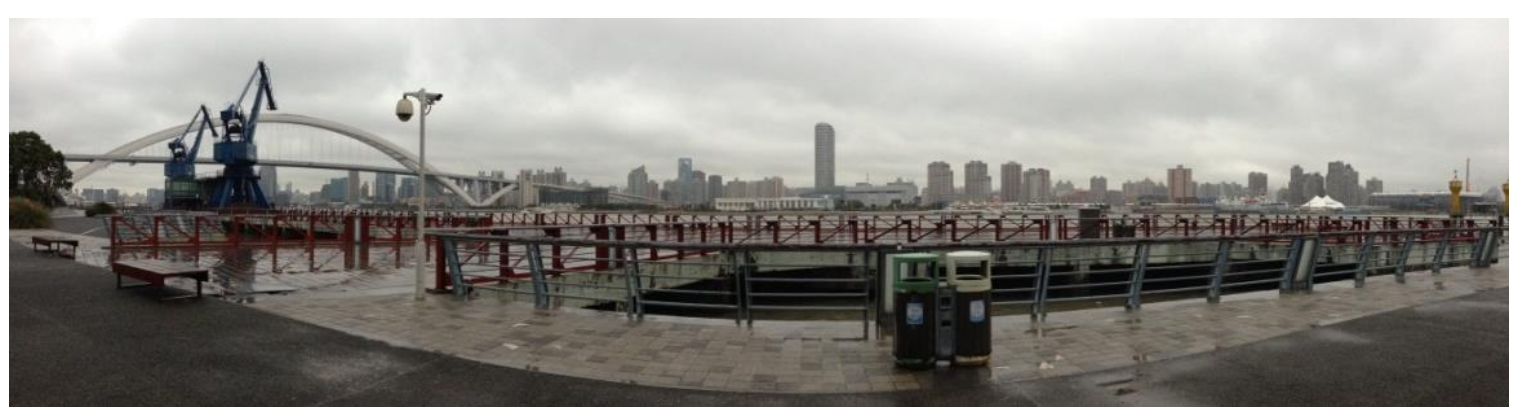

Figure 5: The Shanghai 2010 Expo Park. Source: photo by the authors 


\section{Conclusion and discussion}

The use of cultural approaches in urban regeneration programs to build a city's brand, attract private investment, as well as boost tourism has become widely seen in a host of global cities (Grodach and Loukaitou-Sideris, 2007; Grodach and Seman, 2013). Shanghai, which was regarded as the international consumption city in Chin, has emphasized the use of cultural approaches in industrial land regeneration and industrial heritage reuse. This paper summarized Shanghai's experience on industrial heritage reuse based on the framework of the progressive, creative and entrepreneurial cultural approach, and expanded the main characteristics of the progressive, creative and entrepreneurial cultural approaches into seven aspects, namely, architectural type, potential value, goals, main stakeholders, target audience, type of cultural programs and facilities, and cultural activities. By summarizing the main characteristics of cultural approach to industrial heritage reuse in Shanghai, this paper attempts to in enrich existing literature on urban regeneration and heritage conservation, and provide a reference to the industrial land regeneration practice in China.

\section{Acknowledgements}

This paper was funded by the National Natural Science Foundation of China (Grant No. 52008300).

\section{References}

Ahmad, Y. (2006) The scope and definitions of heritage: from tangible to intangible. International Journal of Heritage Studies, 12(3): pp.292-300.

Bianchini, F. (1993) Remaking European cities: the role of cultural policies. In: Bianchini, F. \& Parkinson, M. (eds) Cultural Policy and Urban Regeneration: The West European Experience, Manchester: Manchester University Press, pp.1-20.

Bullen, P.A (2007) Adaptive reuse and sustainability of commercial buildings. Facilities, 25 (1/2): pp.20-31.

Chen, J., Judd, B. \& Hawken, S. 2016. Adaptive reuse of industrial heritage for cultural purposes in Beijing, Shanghai and Chongqing. Structural Survey, 34(4/5): pp.331-350.

Deng, Y. \& Poon, S.W. (2012) Expo 2010 Shanghai China: a signature chapter of the Huangpu Riverfronts Trilogy. Journal of Place Management and Development, 5 (2): pp.174-191.

Douet, J. (2013) Industrial Heritage Re-tooled: The TICCIH Guide to Industrial Heritage Conservation, New York: Routledge.

Evans, G. (2009) From cultural quarters to creative clusters-creative spaces in the new city economy. In: Legner, M. (eds) The Sustainability and Development of Cultural Quarters: International Perspectives, Stockholm: Institute of Urban History, pp.32-59.

Florida, R. (2002) The Rise of the Creative Class: How It's Transforming Work, Leisure, Community, and Everyday Life, New York: Basic Books.

Griffiths, R. (1995) Cultural strategies and new modes of urban intervention. Cities, 12(4): pp.253-265. 
Grodach, C. \& Loukaitou-Sideris, A. (2007) Cultural development strategies and urban revitalization. International Journal of Cultural Policy, 13(4): pp.349-370.

Grodach, C. \& Seman, M. (2013) The cultural economy in recession: examining the US experience. Cities, 33: pp.15-28.

Judd, D.R. \& Fainstein, S.S. (1999) The Tourist City, New Haven: Yale University Press.

Landorf, C. (2009) A framework for sustainable heritage management: a study of UK industrial heritage sites, International Journal of Heritage Studies, 15 (6): pp.494-510.

Langfield, M., Logan, W. \& Craith, M. N. (2010) Cultural Diversity, Heritage and Human Rights: Intersections in Theory and Practice, New York: Routledge.

Logan, W. (2001) Globalizing heritage: world heritage as a manifestation of modernism and the challenge from the periphery. Proceedings of the Australia ICOMOS National Conference, Adelaide: the University of Adelaide, pp.51-57.

Logan, W. (2007) Closing Pandora's Box: Human Rights Conundrums in Cultural Heritage Protection. In: Silverman, H. \& Ruggles, D. F. (eds) Cultural Heritage and Human Rights. New York: Springer, pp.33-52.

Logan, W. (2012) Cultural diversity, cultural heritage and human rights: towards heritage management as human rights-based cultural practice. International Journal of Heritage Studies, 18(3): pp.231-244.

Montgomery, John (2003) Cultural quarters as mechanisms for urban regeneration. Part 1: conceptualising cultural quarters. Planning Practice and Research, 18(4): pp.293-306.

O'Connor, J. (2011) The cultural and creative industries: a critical history. Economiaz, 78(3): pp.24-47.

O'Connor, J. \& Gu, X. (2014) Creative industry clusters in Shanghai: a success story. International Journal of Cultural Policy, 20(1): pp.1-20.

Pratt, A.C. (2008) Creative cities: the cultural industries and the creative class, Geografiska Annaler: Series B, Human Geography, 90(2): pp.107-117.

Roodhouse, S. (2006) Cultural Quarters Principles and Practices, Chicago: Intellect Books.

Scott, A. J. (1997) The cultural economy of cities. International Journal of Urban and Regional Research, 21(2): pp.323-339.

Taylor, K. (2004) Cultural heritage management: a possible role for charters and principles in Asia. International Journal of Heritage Studies, 10(5): pp.417-433.

TICCIH (2003), The Nichny Tagil Charter for the Industrial Heritage, available at http://www.icomos.org/18thapril/2006/nizhny-tagil-charter-e.pdf.

UNESCO (2003), The Convention for the Safeguarding the Intangible Cultural Heritage, 32nd Session of the General Conference, Paris, available at https://ich.unesco.org/en/convention.

UNESCO (2015) Habitat III Issue Papers- 4: Urban Culture and Heritage, New York, available at http://www.unesco.org/fileadmin/MULTIMEDIA/HQ/CLT/pdf/ISSUE-Paper-En.pdf. 
Vecco, M. (2010) A definition of cultural heritage: from the tangible to the intangible. Journal of Cultural Heritage, 11(3): pp.321-324.

Wilkinson, S. J., Remøy, H. \& Langston, C. (2014), Sustainable Building Adaptation: Innovations in Decision-making, Chichester: John Wiley \& Sons.

Wu, F. (2006) Transplanting cityscapes: townhouse and gated community in globalization and housing commodification. In: Wu, F. (eds) Globalization and the Chinese City. New York: Routledge, pp.190-207.

Yuen, B. (2013) Urban regeneration in Asia: mega-projects and heritage conservation. In: Leary, M.E. \& McCarthy, J. (eds) The Routledge Companion to Urban Regeneration, London and New York: Routledge, pp.127-137.

Zheng, J. \& Chan, R. (2014) The impact of 'creative industry clusters' on cultural and creative industry development in Shangha. City, Culture and Society, 5(1): pp.9-22. 